Check for updates

Montreal, Canada

Cite this as: BMJ 2020;371:m3918 http://dx.doi.org/10.1136/bmj.m3918 Published: 08 October 2020

\title{
Covid-19: FDA defies Trump to publish rigorous vaccine development guidelines
}

\section{Owen Dyer}

President Trump's claim that a covid-19 vaccine could be available before the US election on 3 November has become untenable following the publication of Food and Drug Administration (FDA) guidelines on vaccine development. The guidelines urge companies not to submit applications for emergency use authorisation until they have followed subjects in phase III trials for an average of two months after their last vaccine dose is given.

The guidelines appear to have been given against the president's wishes, the first time in the pandemic that a federal public health agency has explicitly opposed Donald Trump.

"New FDA Rules make it more difficult for them to speed up vaccines for approval before Election Day. Just another political hit job!” Trump tweeted, reproachfully tagging Stephen Hahn, the FDA commissioner.

The FDA first briefed the media two weeks ago to expect strict new guidelines, an announcement that was widely interpreted as a statement of its independence. ${ }^{1}$ Trump-who gave himself authority to interfere in FDA guidance by an executive order in 2019-immediately threatened to stop the guidelines' release.

Clearance by the White House was held up at the insistence of Trump's chief of staff, Mark Meadows, who questioned the need for two months of follow-up. The proposed guidelines would change the rules in mid-trial for the four US companies conducting phase III trials, Meadows argued, suggesting that Hahn was too influenced by FDA career scientists.

But the public health agencies' resolve to resist interference has stiffened of late, as Trump's electoral prospects dim and a daunting flu season approaches. Like several Trump appointees who have pressured FDA or Centers for Disease Control and Prevention staff in recent weeks, Meadows found his comments leaked to the New York Times by anonymous senior officials. ${ }^{2}$ The FDA continued informing the vaccine companies about the new guidance despite the White House hold on clearance.

The vaccine developers backed the FDA. In a letter to health secretary Alex Azar, Michelle McMurry-Heath, president of the Biotechnology Innovation Organisation, the trade association for vaccine developers, wrote, “All new FDA guidance should be finalised and communicated with those on the frontlines developing potential vaccines."3

"Just as importantly, it must also be shared more broadly with the American public. We cannot allow a lack of transparency to undermine confidence in the vaccine development process. The public must have full faith in the scientific process and the rigour of FDA's regulatory oversight if we are to end the pandemic."

Seven former FDA commissioners wrote in the Washington Post that "the Trump administration is undermining the credibility of the FDA." ${ }^{4}$ Among them was Scott Gottlieb, Trump's first appointee to run the agency, who is now a director of Pfizer, the US company closest to completing vaccine trials.

On the afternoon of 6 October, FDA officials were surprised to learn that the White House Office of Management and Budget had cleared the guidance. It was then formally published, having already been posted online in a planning document without White House approval. 5

Trump tweeted his displeasure that evening but gave no hint that he would seek to retract the guidelines. He has continued to claim that vaccines are imminent despite being regularly contradicted by his own officials.

“The vaccines are coming momentarily," proclaimed a video released by Trump immediately after his discharge from hospital on 5 October.

Dyer 0. Covid-19: FDA plans strict vaccine approval criteria, angering Trump. BMJ2020;370:m3741. doi: 10.1136/bmj.m3741 pmid: 32972969

2 LaFraniere S, Weiland N. White House blocks new coronavirus vaccine guidelines. New York Times. 5 October 2020. www.nytimes.com/2020/10/05/us/politics/coronavirus-vaccine-guidelines.html.

3 McMurry-Heath M. Biotechnology innovation organization letter to Health Secretary Alex Azar. 1 October 2020. https://int.nyt.com/data/documenttools/letter-to-the-health-secretary-about-emergency-use-authorizationfor-coronavirus-vaccines/d67f86d1ee10a6f0/full.pdf.

4 Califf R, Gottlieb S, Hamburg M, et al. 7 former FDA commissioners: The Trump administration is undermining the credibility of the FDA. Washington Post. 30 September 2020. www.washingtonpost.com/opinions/2020/09/29/former-fda-commissioners-coronavirus-vaccine-trump. FDA. Development, authorization, and licensure of vaccines to prevent covid-19. 22 October 2020. www.fda.gov/media/139638/download. 